ASSET VALUATION 
By the same author

National and Local Taxation (published by Macmillan Education)

Valuation: Principles into Practice (contributor) (published by Estates Gazette) 


\section{ASSET VALUATION}

\section{MICHAEL RAYNER}

PhD, FRICS

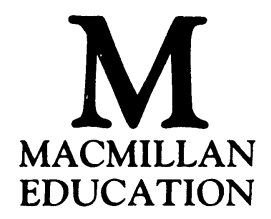


All rights reserved. No reproduction, copy or transmission of this publication may be made without written permission.

No paragraph of this publication may be reproduced, copied or transmitted save with written permission or in accordance with the provisions of the Copyright Act 1956 (as amended), or under the terms of any licence permitting limited copying issued by the Copyright Licensing Agency, 33-4 Alfred Place, London WC1E 7DP.

Any person who does any unauthorised act in relation to this publication may be liable to criminal prosecution and civil claims for damages.

First published 1988

Published by

MACMILLAN EDUCATION LTD

Houndmills, Basingstoke, Hampshire RG21 2XS

and London

Companies and representatives

throughout the world

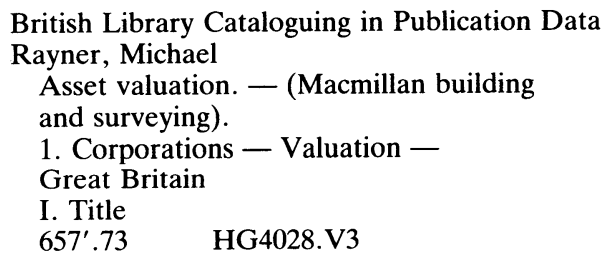

ISBN 978-0-333-36351-5

ISBN 978-1-349-07049-7 (eBook)

DOI 10.1007/978-1-349-07049-7 
To those most valuable assets my grandchildren 


\section{Contents}

Introduction and Acknowledgements ix

1 The Structure and Finance of Companies 1

2 Company Accounts and Inflation Accounting 8

3 Rules and Methods of Valuation 16

4 Valuation: Practical Matters 29

5 Valuation Requirements for Company Accounts 34

6 Valuation Problems and their Solution 43

7 Checks on Valuations 48

References and Bibliography $\quad 55$

$\begin{array}{ll}\text { Index } & 57\end{array}$ 


\section{Introduction and Acknowledgements}

This book is intended as a guide to students of valuation and estate management and I also hope that it will be of some service to practitioners in those arts.

I am pleased to thank many people for their help: first the RICS for permission to quote from their copyright material Guidance Notes; to Charles Hardwick of Trent Polytechnic library without whose magnificent assistance I should not have finished the book; to my former colleagues at Trent Polytechnic; and finally with gratitude to my wife for encouragement and help beyond the call of duty.

Finally, as I write the 'Big Bang' of the Stock Exchange is taking place: I do not think that it will affect any of the matters mentioned in this book but time will tell, and the reader should be aware of this caveat. 